\title{
Realizing the Potentials of Ageing
}

\author{
George W. Leeson ${ }^{1}$
}

Published online: 17 October 2017

(C) Springer Science+Business Media B.V. 2017

\section{Introduction}

The demography of the 20th and 21st centuries was and is one of ageing, both at an individual and at population level (Lee 2003; Leeson 2009, 2014a, b) - and population ageing, which was once regarded as an issue for the developed economies of Europe and North America is truly a global phenomenon now reaching Latin America (Leeson 2011; 2016a, b), the only notable region of exception being sub-Saharan Africa, which remains relatively young in demographic terms (United Nations 2017).

As individuals, we are living longer and longer. Life expectancies at birth have increased at the global level from 47 years in the mid-twentieth century to around 71 years today, and are expected to rise to 78 years by the mid-twenty-first century and to 83 years by the end of the century. As populations, we are also ageing, so that larger proportions of our populations are old. The proportion of the world's population aged 65 years and over has increased from 5\% in the mid-twentieth century to just over $8 \%$ in 2015 , and by 2050 , it is expected to reach almost $16 \%$, equating to more than 1.5 billion people. The end of the century will see $23 \%$ and 2.5 billion of the world's population aged 65 years and over (United Nations 2017).

Europe and North America aged through the twentieth century with Japan joining in the latter part of that century. The populations of much of Asia will age dramatically in the first decades of the twenty-first century, and Latin America will follow suit later this century, meaning their window of opportunity for adaptation to this demographic change remains open for some time to come.

This demographic development in all cases is driven primarily by declining fertility but also by declining mortality ensuring larger and larger proportions of a generation

This paper is based on my opening presentation to the UNECE Regional Research and NGO Forums on Ageing in connection with the UNECE Ministerial Conference on Ageing, held in Lisbon, Portugal, September 20th -22nd 2017.

George W. Leeson

george.leeson@ageing.ox.ac.uk

1 Oxford Institute of Population Ageing, University of Oxford, Oxford, UK 
survive into old age. In the newly ageing populations, fertility decline has often been striking. For example, in the Republic of Korea, fertility declined in the course of just one generation from almost 3 in 1975-80 to 1.23 in 2010-15 (United Nations 2017). Such a dramatic decline in fertility presents huge challenges to individuals, to families, and to society as a whole, not least because many of these societies are largely familybased in respect of support.

At the same time, life expectancies increased equally dramatically during the first half of the twentieth century and then more modestly in the latter half of that century when increases materialised as a result of improvements in survival at older ages (Fries 1980; Leeson 1981, 1982, 2014a, b; Vaupel 1998). The evidence is that our lives will continue to be extended (Bongaarts 2006; Thatcher 1999, 2001; Olshansky et al. 2001; Robine et al. 2003; Wilmoth and Robine 2003; Christensen et al. 2009; Vaupel 2010; Leeson 2011, 2014a, 2016a).

So our lives are longer, and the period of our lives defined as old is becoming an increasing part of our lives. This alone would suggest that we have lost the meaning of old age. In the previous issue of the Journal of Population Ageing, Professor Sarah Harper discusses the reformation of ageing and old age and argues, amongst other things, that we are attempting to tackle the twenty-first century phenomenon of extremely long lives with twentieth century institutions (Harper 2017). In this editorial, I consider how old age is defined and how ageing became interesting and suggest that we need to understand that old age in the twenty-first century is not like old age in the twentieth century. I suggest furthermore that the potentials of ageing cannot be realized until we acknowledge this and act accordingly old age.

\section{What Is Old Age?}

The idea of old age is nothing new and scholars since classical times have waxed lyrical about the positive and negative sides of old age. Cicero (106-43 B.C.) was a Roman statesman and philosopher who wrote De Senectute (On Old Age) in 44 B.C. when he was 62 . His analysis and observations on growing older in this work are timeless. In De Senectute, Cicero assumes the persona of 84 year old Cato the Elder, who had lived about 100 years earlier. Cato is having a discussion with two younger men, and these young men, admiring the way Cato has borne the increasing burdens of growing old, ask him on what principles they could rely to allow them to do the same. He gives four reasons why old age is regarded as an unhappy time of our lives:

"I find four reasons why old age appears to be unhappy: first, that it withdraws us from active pursuits; second, that it makes the body weaker; third, that it deprives us of almost all physical pleasures; and, fourth, that it is not far removed from death."

Cicero - in the guise of Cato - proceeds to analyze and dismiss each of these reasons, ending with:

“...my old age sits light upon me..., and not only is not burdensome, but is even happy. For as Nature has marked the bounds of everything else, so she has marked the bounds of life. Moreover, old age is the final scene, as it were, in life's drama, from which we ought to escape when it grows wearisome and, certainly, when we have had our fill." 
At the end of the sixteenth century, Shakespeare provided us with the seven ages of man in his play As You Like It. It is here that the melancholy traveller Jacques delivers what could arguably be the best known monologue in all of Shakespeare's works. He begins:

"All the world's a stage,And all the men and women merely players, They have their exits and entrances,And one man in his time plays many parts,His acts being seven ages."

Jacques proceeds to describe these seven ages of man, ending with the 5th 6 th and 7 th:

"And then the justiceIn fair round belly, with good capon lin'd,With eyes severe, and beard of formal cut,Full of wise saws, and modern instances,And so he plays his part. The sixth age shiftsInto the lean and slipper'd pantaloon,With spectacles on nose, and pouch on side,His youthful hose well sav'd, a world too wide,For his shrunk shank, and his big manly voice,Turning again towards childish treble, pipesAnd whistles in his sound. Last scene of all,That ends this strange eventful history,Is second childishness and mere oblivion,Sans teeth, sans eyes, sans taste, sans everything."

It is this last scene of all that defines old age for centuries to follow, a return to childhood and a time of total dependency. Note, however, in modern times, that Shakespeare's 5th and 6th ages of man come to be packaged into old age, and it is from this misleading and - for those packaged in this way - unfortunate definition that Laslet 1989) wants to deliver us, introducing the 3rd and 4th ages in his original (and controversial) book A Fresh Map of Life - the Emergence of the Third Age.

Old age and all of its associated stereotypical images are linked to retirement. The history of retirement is one of a development from a rest at the end of a long, hard working life, a rest that would last a few short years for those even lucky enough to survive to retirement age, to a reward for those who had sacrificed so much for their country in two world wars, to a right in the 1970s and 1980s when early retirement schemes were introduced to make way for the unemployed youth of Europe and North America. Oxford's Global Ageing Survey suggests retirement is now regarded as a responsibility, where those who are being forced to retire want to continue to contribute to society in a variety of ways (Leeson and Harper 2006, 2007a, b, c, 2008). The first social pension schemes which enabled retirement from economically productive activity (narrowly defined in an industrial age fashion) appeared with age thresholds of around 65-70 years and with accompanying restrictions. At that time - the end of the 19th / beginning of the 20th centuries - life expectancies were around 50 years (Leeson 2016a). Today, life expectancies are around 80 years in much of the world, but pension schemes still operate with age thresholds which have changed little since those pioneer pension schemes were introduced. There is clearly a disconnect between pension thresholds and life expectancies as we continue to suggest twentieth century solutions for 21 st and even twenty-second century issues.

The concept of retirement has forced us to find roles for old age - this is not realising the potential of ageing. We need to re-define old age as that final (short) time before 
death (Harper 2017), prior to which we are older adults contributing in all manners to our families, our communities, our workplaces and society.

\section{When Did Ageing Become Interesting?}

There are (at least) three institutional structures which historically defined older people as a separate group from everyone else in a population. These three structures are almshouses, ${ }^{1}$ the pensions systems introduced increasingly in Western Europe from around the end of the nineteenth century, and the development of geriatrics as a medical speciality.

From the eighteenth century, almshouses developed from institutions for poor disadvantaged of all ages (with older people a small minority among them) to institutions populated by older people, a result of the development of welfare for specific groups (poor, sick, disabled). This unfortunately meant that the group of (all) older people becomes homogenised into this group - the exciting and complex heterogeneity of old age is lost. Thus, almshouses institutionalised a marginalised social space for older people.

On the other hand, pensions systems introduced a marginalised social time defining old age. Indeed, they define an exact age beyond which citizens become dependent, separated from the younger productive section of the population. In this way, a welldefined phase of life called old age becomes anchored in society's judicial and administrative structure. A collective perception of old age as a well-defined, chronologically determined phase of life appears from the middle of the nineteenth century. The statistical preconditions needed to regard older people as a well-defined group within legislation are to a great extent linked to the work of the Belgian statistician, Quetelet (1796-1874):

"Man is born, grows up, and dies, according to certain laws which have never been properly investigated......." (Quetelet 1835).

This approach opens the floodgates for a standardised definition of old age based on statistical probabilities, and along with this comes the opportunity to treat and understand older people collectively as a group in a chronologically well-defined phase of life. This statisticalisation of old age provides a scientific platform for the introduction of social support mechanisms in old age.

This in turn is closely related to the final institutional structure - the medicalisation of the ageing body/person. Geriatrics is born as a discipline around 1840 and has Quetelet as its actual and most important basis (Kirk 1995).

Medicine came to dominate ageing - it was about defying ageing and even defying death. The medicalisation of ageing - helped by the marginalisation of old age and older people mentioned above - led to the dominant image of ageing and old people as one characterised by the tired, failing ageing body. The 7th age of man described by Shakespeare as second childishness fitted this image perfectly. Medicine claimed a

\footnotetext{
${ }^{1}$ An almshouse provided shelter in a community for people who could no longer work to earn enough money to pay rent and they were therefore primarily for the poor. As such, stigma was attached to them.
} 
monopoly on even the social construction of old age. It was here the research was focused - in ill health and combatting this ill health. This remained the dominant feature of ageing research really until around the mid-twentieth century - what happened then?

\section{The Emergence of Gerontology}

What happened was gerontology. Gerontology is distinguished from geriatrics, which is the branch of medicine that specializes in the treatment of existing disease in older adults, and it is also distinguished from geratology, which is the branch of biology that studies aging, in as much as it encompasses all aspects of ageing as a life process. Gerontologists include researchers in the fields of demography, biology, nursing, medicine, criminology, dentistry, social work, physical and occupational therapy, psychology, psychiatry, sociology, economics, political science, architecture, geography, pharmacy, public health, housing, and anthropology, and others no doubt. It was not until the 1940s that pioneers like James Birren began organizing gerontology into its own field, and the Gerontological Society of America was founded in 1945. The British Society was not founded until 1971.

At the same time as this disciplinary development, society was also moving and developing. The modern welfare state begins to expand across the world. The welfare state is not just about the provision of support, however, it is all about rising living standards - people are living longer and retiring earlier. As already mentioned, the early retirement schemes of the 1970s and 1980s in Europe and North America, introduced to create jobs for the unemployed youth, redefine the collective perception of and attitude to old age dramatically. This is a redefining of the space and time of old age.

The issue, however, is that someone aged 60 years is now expected to join the collective ranks of old age, slotting neatly into the stereotypical image of old age built up over the previous 150 years or so. How can they be expected to do this, given everything we now about their health and life expectancy? Of course, they can't.

Gerontological research took to researching this new old age, explaining and evidencing the potential rather than the burden and misery of old age, and at the same time civil society organisations began to campaign against this collective marginalisation of older people.

\section{The Potentials of Ageing}

Put quite simply, given increasing life expectancy and longevity, humans potentially have the opportunity to contribute to their families, communities, and workplaces for much longer - breaking through the legislative and administrative age barrier that constrains them and redefining old age in the life course.

We are living longer, healthier and more active lives - we have added 2.5 years per decade for the last 160 years (Westendorp 2004), and there is as yet no evidence of having reached a limit to human lifespan.

Realising and releasing the potential of ageing is not a question of finding meaningful roles in old age, while continuing to marginalised older people collectively. 
Realising and releasing the potential of ageing is about redefining old age. It is about extending our active contributory life, in whatever way we want to define this as individuals, into our 70s and 80 s and even 90 s before real old age begins to reduce our potential for this.

Releasing and realising this potential requires a serious raising of awareness - an awareness of our lives and the length of these lives.

Research should provide evidence for policy to enable us all to benefit from our long lives and not be disadvantaged, and it should provide evidence for practice to provide supportive structures in all spheres of life, and research should also provide evidence for us as individuals so that we can make reasoned and qualified choices about our future lives.

All of this is particularly true in the post truth information era in which we apparently find ourselves. Information is confused with knowledge. Information is everywhere, there is information overload, and few if any of us are positioned to digest, understand and conclude from this information. In confusing information and knowledge, we have all become experts. This makes the role of research even more important.

Research cannot realise and release the potential of ageing alone. Governments have an equally important role and so do we as individuals. We too are stuck in the old age of our parents and grandparents. While the old ages of our parents and grandparents may not have been that different from one another, the developments of the last 50 years mean that our old age will be very different, just as that of the current 5 th, 6th and 7 th old agers of Shakespeare is different.

First of all, we need to wake up to the fact that 3 score years and 10 has long gone. It's now 4 score years and 10 and may well become 5 score years and 10 for our children and grandchildren (Leeson 2016a). Waking up to this means waking up to a new realisation with regard to work, leisure and financial preparation.

Much of the research into ageing has been about (poor and declining) health and financial disadvantage. This was important and justified. And while these are still issues, they alone do not contribute to realising the potential of ageing. A more holistic approach is necessary - also reflecting the importance of life course decisions and conditions - one which includes housing, transport, technology, education and work.

Research needs to maintain its independence, its integrity and above all its ideals. And perhaps most importantly, we all have to take on the cloak of this new old age.

\section{References}

Bongaarts, J. (2006). How long will we live. Population and Development Review, 32(4), 605-628.

Christensen, K., Doblhammer, G., \& Vaupel, J. (2009). Ageing populations: The challenges ahead. Lancet, 374(9696), 1196-1208.

Fries, J. F. (1980). Aging, natural death and the compression of morbidity. The New England Journal of Medicine, 303(3), 130-135.

Harper, S. (2017). The reformation of age and ageing. Journal of Population Ageing, 10(3), 201-205.

Kirk, H. (1995). Da aldermen blev en diagnose. Copenhagen: Munksgaard.

Laslet, P. (1989). A fresh map of life - The emergence of the third age. London: Weidenfeld and Nicolson.

Lee, R. (2003). The demographic transition: Three centuries of fundamental change. Journal of Economic Perspectives, 17(4), 167-190. 
Leeson, G.W. (1981). Ældres dødelighed 1960-1980 (the mortality of older people in Denmark, 1960-80), Ugeskr. Læger, 143, pp. 2324-7.

Leeson, G. W. (1982). Demographic ageing in Denmark in the 20th century. The Eugenics Society Bulletin, $14,46-52$.

Leeson, G. W. (2009). Demography, politics and policy in Europe. In Setting EU Priorities 2009 (ed. Ludlow, $P)$ (pp. 102-124). Ponte de Lima, Portugal: The European Strategy Forum.

Leeson, G. W. (2011). Prepared or not, Latin America faces the challenge of aging, Current History. Journal of Contemporary World Affairs, 110(733), 75-80.

Leeson, G.W. (2014a). Future prospects for longevity, Post Reproductive Health, Vol. 20 (1), pp. 17-21.

Leeson, G. W. (2014b). Increasing longevity and the new demography of death. International Journal of Population Research, 2014, 521523-521527. https://doi.org/10.1155/2014/521523.

Leeson, G.W. (2016a). Increasing longevity and family dynamics in Latin America, in Larna Argentina 2014 : Seminario Diversidad cultural y envejecimiento : la familia y la comunidad (eds. Ricardo Iacub et al) Ciudad Autónoma de Buenos Aires,, pp. 304-329, ISBN 978-987-42-1283-2, 2016.

Leeson, G.W. (2016b). The impact of mortality development on the number of centenarians in England and Wales, Journal of Population Research, Springer, 23 September 2016, pp. 1-15. https://doi.org/10.1007 /s12546-016-9178-8.

Leeson, G. W., \& Harper, S. (2006). The global ageing survey (GLAS) - Attitudes to ageing and later life, research report 106. Oxford Institute of Ageing: University of Oxford, Oxford.

Leeson, G. W., \& Harper, S. (2007a). The global ageing survey (GLAS) - ageing and later life, United Kingdom and Europe, research report 107. Oxford Institute of Ageing: University of Oxford, Oxford.

Leeson, G. W., \& Harper, S. (2007b). The global ageing survey (GLAS) - ageing and later life, the Americas, research report 207. Oxford Institute of Ageing: University of Oxford, Oxford.

Leeson, G. W., \& Harper, S. (2007c). The global ageing survey (GLAS) - ageing and later life, Hong Kong and Asia, research report 307. Oxford Institute of Ageing: University of Oxford, Oxford.

Leeson, G. W., \& Harper, S. (2008). Some descriptive findings from the global ageing survey (GLAS) Investing in later life, research report 108. Oxford Institute of Ageing: University of Oxford, Oxford.

Olshansky, J., Carnes, B. A., \& Desesquelles, A. (2001). Prospects for human longevity. Science, 291(5508), 1491-1492.

Quetelet, A. (1835). A Treatise on man and the development of his Faculties, published under this title in English in1842. Edinburgh: William \& Robert Chambers.

Robine, J.-M., Saito, Y., \& Jagger, C. (2003). The emergence of extremely old people: The case of Japan. Experimental Gerontology, 38, 735-739.

Thatcher, R. (1999). The demography of centenarians in England and Wales, Population Trends, 96. London: Office for National Statistics.

Thatcher, R. (2001). The demography of centenarians in England and Wales. Population; An English Section, 13(1), 139-156.

United Nations (2017). World Population Prospects: 2017 Revision, United Nations, Department of Economic and Social Affairs, New York.

Vaupel, J. (1998). Demographic analysis of aging and longevity. The American Economic Review, 88(2), 242247.

Vaupel, J. (2010). Biodemography of human ageing. Nature, 464, 536-542.

Westendorp, R.G.J. (2004). Are we becoming less disposable? EMBO Rep., Vol. \% (1), pp.2-6.

Wilmoth, J. R., \& Robine, J.-M. (2003). The world trend in maximum life span. Population and Development Review, 29, 239-257. 